DOE /60/10/47-- 4A-P.9

Biomass Energy Production Effects on Environment

\title{
Impact of Alfalfa on Soil \\ and Water Quality
}

MINNESOTA AGRIPOWER PROJECT

TASK III RESEARCH REPORT

Padam Sharma, John Moncrief, and Satish Gupta

University of Minnesota

Department of Soil, Water and Climate \&

West Central Experiment Station

October 30, 1997

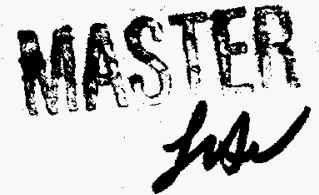




\section{DISCLAIMER}

This report was prepared as an account of work sponsored by an agency of the United States Government. Neither the United States Government nor any agency thereof, nor any of their employees, makes any warranty, express or implied, or assumes any legal liability or responsibility for the accuracy, completeness, or usefulness of any information, apparatus, product, or process disclosed, or represents that its use would not infringe privately owned rights. Reference herein to any specific commercial product, process, or service by trade name, trademark, manufacturer, or otherwise does not necessarily constitute or imply its endorsement, recommendation, or favoring by the United States Government or any agency thereof. The views and opinions of authors expressed herein do not necessarily state or reflect those of the United States Government or any agency thereof. 


\section{DISCLAIMER}

Portions of this document may be illegible electronic image products. Images are produced from the best available original document. 


\section{Table of Contents}

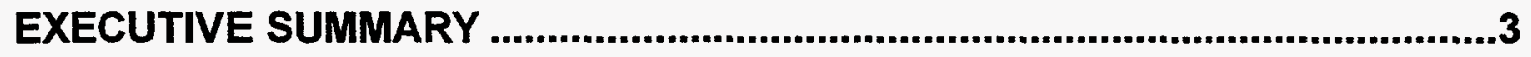

BACKGROUND.............................................................................................................4

RESEARCH GOALS AND DELIVERABLES ......................................................5

RESEARCH METHODOLOGY ..........................................................................6

PAIRED WATERSHED STUDY AT MORRIS........................................................................................... 6

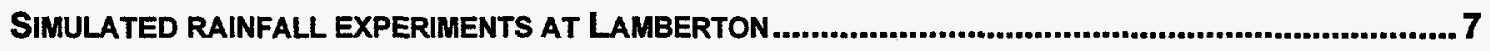

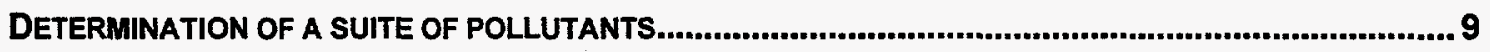

EFFECT OF ALFALFA CUTTING FREQUENCY ON SOIL WATER USE ................................................ 9

RESULTS AND DISCUSSION ..........................................................................10

RUNOFF AND POLLUTANT DELIVERY FROM PAIRED WATERSHEDS AT MORRIS .................................. 10

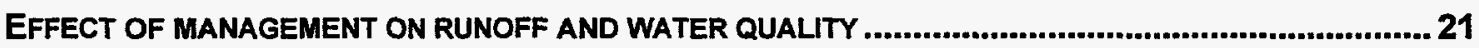

EFFECT OF ALFALFA CUTTING FREQUENCY ON SOIL WATER USE .................................................... 25

CONCLUSIONS...........................................................................................................28

LITERATURE CITED............................................................................................29

ACKNOWLEDGMENT.........................................................................................30 


\section{Executive Summary}

Dominance of row crop agriculture in rolling landscapes of western and south-western Minnesota is identified as a primary, non-point source of sediments and associated pollutants reaching the Minnesota River. Currently as a biomass energy project, alfalfa is being promoted in western Minnesota to harvest the leaves for animal feed and stems to generate electricity. As a perennial, leguminous crop grown with minimum inputs, introduction of alfalfa in row cropped lands has potential to improve both in-situ soil productivity and downstream water quality.

A field study was initiated in 1996 to compare the volume of runoff and pollutants coming from alfalfa and corn-soybean fields in western Minnesota. Two pair of alfalfa and corn-soybean watersheds were instrumented at Morris in the Fall of 1996 to measure rainfall, runoff, and sample water for sediment load, phosphorus, nitrogen, biochemical oxygen demand, and chemical oxygen demand.

Runoff hydrographs of the record snow-melt during the spring of 1997 at Morris show alfalfa fields yielding more runoff than corn-soybean fields due to presence of more snow on alfalfa fields. The chemographs relating the loading of a suite of pollutants from cumulative runoff show alfalfa fields yielding more ammonium than the corn fields while the corn fields tended to yield more sediments, nitrate, DMRP, bio-available $P$, and total $P$. There was no appreciable trend in the distribution of BOD and COD between the corn and alfalfa fields. For the summer 1997 precipitation induced runoff events, the soybean fields yielded more runoff, sediment, $\mathrm{COD}$, and nitrate than the alfalfa fields.

Simulated rainfall-runoff experiments were conducted on an existing crop rotation - input management study plots at Lamberton to evaluate soil quality effects of the inclusion of alfalfa in a com-soybean rotation under manure and fertilization management schemes. In general, soybean fields following alfalfa and corn under four-year (corn-soybean-oat-alfalfa) rotation with manure based management had higher infiltration capacity. This is attributed to improved soil quality due to possible increase in aggregation and macroporosity as a result of decomposition of alfalfa biomass and manure application on corn.

Alfalfa soil water use as a function of frequency of harvest was also monitored at Morris to evaluate the effect of cutting schedule on soil water use. During the growing season of 1997, alfalfa under a two-cut management scheme used about $25-\mathrm{mm}$ (an inch) more soil water than under a three-cut schedule. The mean differences between the treatments were not significant.

The conclusions drawn in this report come from analysis of data collected during one winter-summer hydrologic and crop management cycle. Continued observations through a period of at least 3-5 years is recommended to improve the instrumentation robustness and discern the variability due to climate, soil, and crop management factors. 


\section{Introduction and Objectives}

In justification of the proposed Minnesota Agri-Power Project, Westinghouse Technology Bulletin No. 59 states, "Alfalfa is a renewable resource that provides significant environmental, agricultural and economic benefits. By improving soil and water quality and wildlife habitat, alfalfa production sustains agricultural productivity and environmental quality." The research focus of this project is geared towards quantifying the above statement by measuring how much of the precipitation water enters into the soil (hence, utilized for biomass production) and how much water runs off (and hence, carrier of sediments and pollutants) the field of alfalfa vs. existing corn-soybean fields.

Management of water is the key to environmentally and economically sustainable production of alfalfa. Compared to annual crops of corn and soybean, alfalfa uses higher amounts of water from a deeper root zone. The desirable management objective for the farmers is to maximize utilization of precipitation water in the field and improve the productivity of soil for succeeding crops in the rotation. The desirable land use management objective for the state is to minimize runoff and erosion from lacustrine landscapes and nitrate leaching to ground water from glacial outwash plains in the proposed alfalfa crop expansion area in Western Minnesota. The goal is to improve the surface and ground water quality of the Minnesota River basin and its tributaries. The specific objectives of this phase of environmental research program which states, "Measure the impact of introduction of alfalfa in a corn-soybean rotation on erosive losses of a suite of pollutants", is in the interest of both the alfalfa farmer and the public at large.

\section{Background}

The Minnesota River is one of the 20 most polluted waterways in the United States. A significant part of the Minnesota River's water quality problem comes from sediment that enters the river and its tributaries throughout its 4-million-hectare watershed predominantly used for row-crop agriculture. Continuous corn, small grains, and corn-soybean cropping systems dominate the agricultural land use practices in the Minnesota River basin.

As a general rule, soil erosion occurs during early season when the exposed soil surface in a row-cropped field is acted upon by high volume snow-melt runoff and raindrop impact from spring precipitation events. As the season progresses and a crop cover is established, the erosion rates decrease. Adoption of high residue, conservation tillage practices significantly reduce soil erosion from the row-cropped agricultural lands. However due to low adoption, the water quality benefits of conservation tillage systems have yet to be realized. Specifically, a full adoption of conservation tillage systems is critical on the highly erodible, gently to steeply rolling, row-cropped landscapes prevalent in the Minnesota River basin.

A general strategy for the management of agricultural lands and reducing the delivery of pollutants to the Minnesota River would involve efforts to (1) improve and sustain soil quality through adoption of conservation and sustainable tillage practices, and (2) improve the efficiency and application of farm inputs, including nutrients and crop protection products. The goal is to improve on-farm productivity and reduce the off-farm delivery of sediment, nutrients, and pesticides due to erosion, runoff, and drainage.

Compared to row crop agriculture, an established crop of forage such as alfalfa provides continuous surface cover throughout the growing season. Alfalfa is a perennial crop which following winter dormancy or cutting regrows from the crown. Alfalfa grows under diverse environmental conditions and tolerates 
extremes in temperature and survives severe moisture deficits. In Minnesota, adapted disease resistant varieties usually maintain productive stands for 4 years following the seeding year. Alfalfa needs a minimum of fertilization and pesticides.

Being a deep rooted leguminous crop, alfalfa enhances soil quality through improvement in fertility and soil structure. Improved soil quality means increased onsite productivity due to increased storage of precipitation water in the root zone and decreased offsite delivery of runoff and pollutants. Available research information on the effect of forage crop such as alfalfa following continuous corn-soybean rotation in the United States and other countries around the World indicate positive improvement in soil structure and fertility over time. Introduction of alfalfa into a row crop rotation shows promise of meeting above mentioned strategies and goals of judicious soil management and improve the water quality of Minnesota River.

\section{Research goals and deliverables}

Interpretations of research results conducted in a different physiographic region is subject to variability of climate, soil, landscape characteristics, and management practices specific to that region. To systematically document the perceived "mostly positive" effects of introduction of alfalfa into the cornsoybean cropping system in western Minnesota and assure sustained availability of alfalfa to the proposed power plant in the future, the overall research goal is to evaluate:

- best management practices for alfalfa and succeeding crops in the cropping sequence

- changes in indicators of soil and water quality over time

- effect of alfalfa based land use on Minnesota River water quality

For this phase of the environmental research, the following deliverables were set:

a) Establishment of small, paired watershed study sites to evaluate the total effect of alfalfa in the rotation on runoff and losses of total $\mathrm{P}$, soluble $\mathrm{P}$, bioavailable $\mathrm{P}$, sediment, ammonium, and nitrate.

b) Instrumentation of the watersheds with rain-gages, flumes, flow sensors, water quality samplers, and data loggers to continuously monitor snow-melt and precipitation-runoff events throughout the year

c) Development of protocol for runoff sample collection, handling, transportation, and determination of soluble $P$, total $P$, bioavailable $P$, sediment, nitrate, ammonium, biochemical oxygen demand, and chemical oxygen demand.

d) Characterization of watersheds and soils with detailed topographic and soil surveys

e) Analysis of data from each runoff event with hydrographs, chemographs, and appropriate statistical tools. 


\section{Research Methodology}

\section{Paired watershed study at Morris}

The studies are carried out at the University of Minnesota, West Central Experiment Station located at the east edge of Morris in Stevens County, Minnesota (T. 125N, R. 41W). The soils are primarily formed on calcareous loamy glacial till (Rust and Erickson, 1971). The relief of the area surrounding the station is nearly level to gently and steeply rolling till moraine deposits through which the Pomme de Terre River Valley is carved out. The study area is dominated by gently sloping to hilly, well-drained Buse-BarnesForman soil association which are mostly loam or clay loam soils. The dominant soil series at the watershed experiment site include the well drained, gently (2-6\%) to moderately sloped (6 - $12 \%$ slopes), Barnes - Buse loam and the steeply sloping ( $12-18 \%$ slopes), Buse - Barnes loam (Lewis et. al, 1971).

Four field size watersheds laying east-west and draining south were selected on the east $1 / 2$ of West Central Experiment Station field E-5. Figure 1 shows the general relief of the study area. The fields were under wheat in 1995 and they were chisel plowed in the fall after harvest of the wheat crop. The eastern $(0.65$ ha with designation Plot-5) and the western (1.78 ha with designation Plot-8) fields were seeded with alfalfa in 1996. The central two watersheds (total of 1.82 ha with designation Plot-6 and Plot-7) were seeded with corn in 1996. The corn was harvested for grain in October and plowed in November 1996 using a coulter chisel plow with 4-inch twisted shovels (Glencoe Soil Shovels). Corn stalks were not chopped. The alfalfa fields were seeded on May 28 with variety MP2000 and harvested on July 17, 1996. Both the fields were inter-seeded with MP2000 on August 8 to reinforce the stand. A second cutting of alfalfa was done on August 29, 1996.

At the lower boundaries of each field, earthen berms were constructed to guide water towards the flumes. A flume is a specially shaped open channel structure which converges the incoming flow, guides through its neck, and diverges the flow as it exits the flume. The flow rate through the flume is a function of liquid level in the flume.

We used two fiberglass constructed flumes in sequence to capture and measure the flow coming out of each watershed. A 6-inch Parshall flume was located at the convergence point of the berms, and water then passed through a 4-inch Paimer Bowlus flume at the down slope end. The two flumes were selected to accommodate both large and small flows expected to occur during runoff events. The Parshall flumes were installed and leveled during the Fall of 1996. The smaller Palmer-Bowlus flumes were installed and leveled during second week of March 1997, just before the beginning of snow-melt event.

Along the side of the two flumes at each watershed, an instrument shelter was constructed to house a Champbell Scientific 21-X data logger, an ISCO water sampler, a gas cylinder, and batteries for power backup. A 110-V electrical power source was also connected to each instrument shelter. A pressure differential transducer was connected with tygon tubing to a gaging tube at each flume to measure the level of water in the flumes. The tygon tubing carried $\mathrm{N}$-gas at a constant rate. The pressure with which the gas bubbles as it comes out of water is proportional to the height of water in the flume. The pressure difference is measured in voltage with the transducer. Each transducer was individually calibrated to convert volt readings into height of water which was then used to calculate the flow rate passing through the flumes. A recording raingage and three copper-Constantan thermocouples were connected to the data logger to measure rainfall, water, air, and soil/snow temperatures. A 24-bottle ISCO water sampler at each site was individually programmed to sample runoff water during a flow period.

A program was written for the data-logger to sense the instruments every 30 seconds and record cumulative precipitation and flow every five minutes. Whenever there was a minimum depth of flow, the 
program triggered the ISCO sampler to collect $65-\mathrm{ml}$ of runoff water every five minutes. Twelve subsamples were composited into a one-liter bottle representing an hour of flow. From the bottles collected during the flow event of the past 24-hour period, representative samples were transported the same day to the University of Minnesota, Soil Water \& Climate laboratory at St. Paul for determination of biochemical oxygen demand. Remaining water samples were refrigerated at West Central Experiment Station in Morris. The samples were conveniently transported to St. Paul to determine sediment load, chemical oxygen demand, dissolved phosphorus, bioavailable phosphorus, total phosphorus, ammonium, and nitrate nitrogen.

\section{Simulated rainfall experiments at Lamberton}

A Variable Input Crop Management (VICM) study has been underway at Southwest Experiment Station (SWES) at Lamberton since 1989 to evaluate the performance of a two-year corn-soybean (CS) rotation vs. four-year corn-soybean-oat-alfalfa (CSOA) rotation under different levels of input management (Perillo et al., 1996). The management treatments include two themes: Commercial fertilizer-herbicide based system and manure-mechanical weed control system.

After more than seven years of the inception of this study at Lamberton, it is assumed that the crop rotation and management treatments are beginning to show effects on soil quality. The objective of this phase of rainfall simulation study was to document the crop rotation and management effects on soil quality by measuring infiltration, runoff, and water quality.

The rainfall simulation experiments were conducted during April 21-26, 1996, on over-winter residues of four soybean and four alfalfa fields. Two soybean fields were on CS rotation under fertilizer-herbicide management, and two were with CSOA rotation under manure-mechanical weed control system.

Similarly, a pair each of the alfalfa fields were interseeded with oat after corn-soybean crops under fertilizer and manure management, respectively.

Briefly, the fertilizer-herbicide management system involved primary tillage with chisel plow following corn, moldboard plow following alfalfa, and no-till following soybean (with secondary tillage before planting). Dependent on crop residue and soil conditions, disc or field cultivators are used for pre-planting secondary tillage. Crops are planted in 30 -inch $(0.76 \mathrm{~m})$ rows for corn and soybean and oat is drilled with alfalfa undersown. Fertilizers are band placed based on soil tests (NPK), previous crop, and a realistic yield goal. Both mechanical and chemical methods are used for weed control.

For manure treatment, primary tillage is done with moldboard plow following corn and alfalfa and with chisel plow following soybean. Disc and field cultivators are used for weed control before planting. The corn crop in the four year rotation receives solid beef manure and the 2-yr rotation receives liquid hog manure at rates based on soil tests. The weeds are controlled only mechanically with rotary hoe and row cultivator.

A Purdue-type sprinkling rainulator was used to rain on 30 -inch $(0.76 \mathrm{~m})$ by $24-\mathrm{ft}(7.31 \mathrm{~m})$ runoff plots prepared with corrugated metal boarders and collection troughs. Water pumped with about $6 \mathrm{lb}^{-\operatorname{In}^{-2}}(41.4$ $\mathrm{kPa}$ ) pressure is supplied to the simulator nozzles to mimic approximate terminal velocity of natural rainfall. The rainfall intensity was adjusted to 2 inch. $\mathrm{h}^{-1}(50.8 \mathrm{~mm})$ until steady state runoff measurements were obtained. When plots with high infiltration rates did not yield any runoff for 2 hours of water application, the application rates were increased to 3 inch. $h^{-1}(76 \mathrm{~mm})$.

After the initiation of runoff, water samples were collected every 5 minutes for determination of runoff volume until steady state runoff rates were observed. The water samples were transported to University of Minnesota, Department of Soil, Water and Climate laboratory for analysis of sediment load, total phosphorus, dissolved phosphorus, and chemical oxygen demand. 


\section{WATERSHED STUDY AT MORRIS SURFACE ELEVATION}

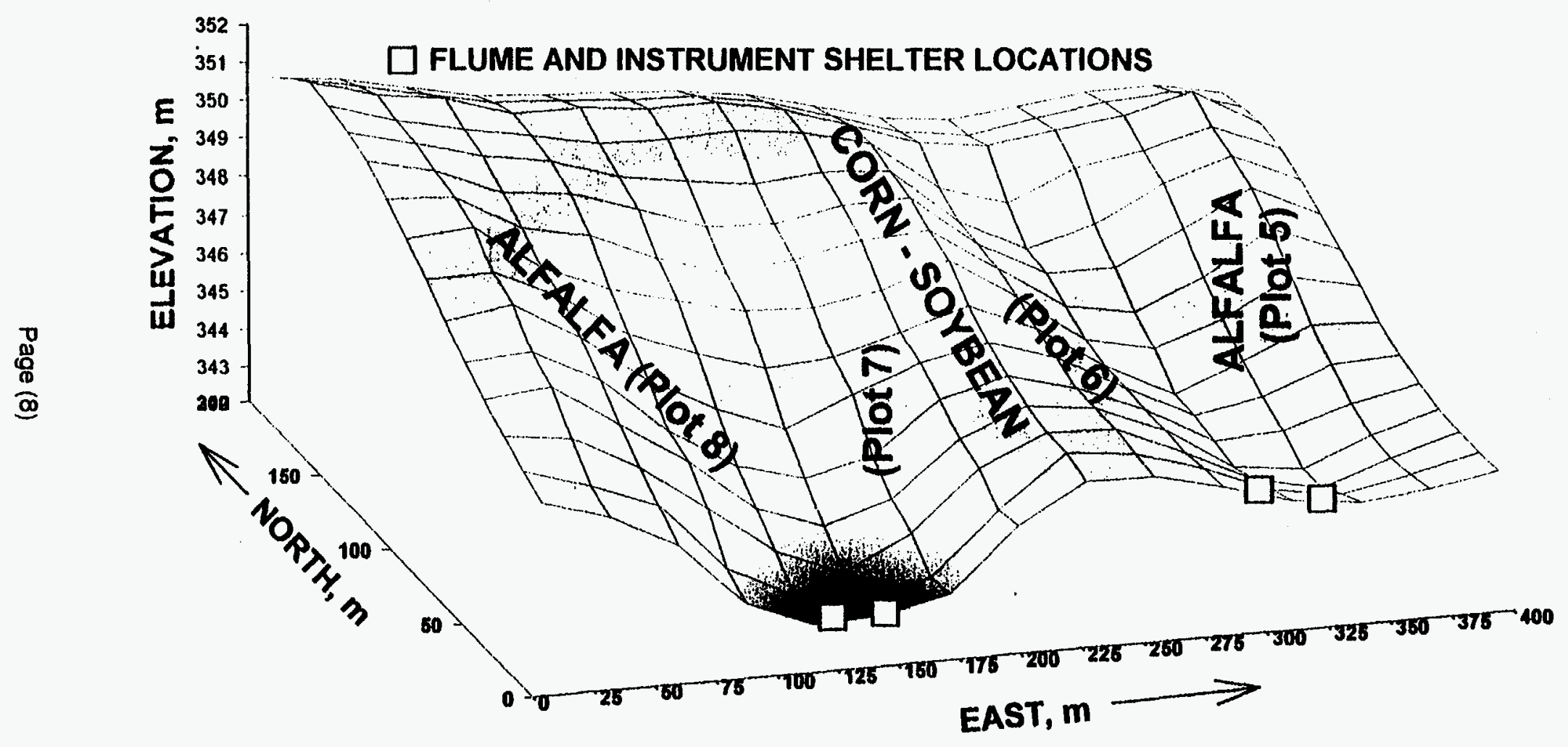

Fig. 1: Approximate surface topography and location of the four watershed plots at the alfalfa water quality study site in Morris. 


\section{Determination of a suite of pollutants}

Sediment in water often leads to impaired habitat for aquatic life, and decreased photosynthetic activity. Sediment concentration is determined by thoroughly shaking the sample and evaporating a known volume of sub-sample by oven drying at $104^{\circ} \mathrm{C}$ (US-EPA, 1971).

Excessive levels of phosphorus often promote eutrophication, which results in the depletion of oxygen in nutrient rich waters with abundant algal growth.

We tested the water samples for three indicators of phosphorus, namely; Dissolved Molybdate Reactive Phosphorus (DMRP), Bioavailable Phosphorus (BP), and Total Phosphorus (TP). The DMRP measures phosphorus in solution, and the TP indicates both the dissolved and sediment-adsorbed phosphorus. The $\mathrm{BP}$ is an estimate of phosphorus (both dissolved and adsorbed) that would be available for growth of aquatic vegetation.

After filtration of water samples with glass fiber membrane filter, the DMRP was determined using Mo blue method (US-EPA, 1971). The total phosphorus (TP) was determined by digesting with $\mathrm{HNO}_{3}$ and $\mathrm{HClO}_{4}$ and neutralization with $\mathrm{NaOH}$ (Olson, and Sommers, 1982). The bioavailable phosphorus is determined by mixing thoroughly with $\mathrm{NaOH}$ and neutralization with $\mathrm{H}_{2} \mathrm{SO}_{4}$ (Sharpley, et al., 1992).

Nitrogen is a source of nutrients for biomass production in the aquatic habitat, and excessive nitrates in drinking water is known to cause health problems for infants. Ammonium is determined by gas diffusionconductivity method by passing alkaline reagent treated sample solution through a gas permeable membrane into an $\mathrm{NH}_{3}$-absorber solution of known conductivity (Carlson et al., 1990). Nitrate is quantitatively reduced to $\mathrm{NH}_{3}$ by Cu${ }^{++}$activated granular $\mathrm{Zn}$ column in the reagent stream. The $\mathrm{NO}_{3}$ concentration is calculated by subtracting the $\mathrm{NH}_{4}$ determined without the $\mathrm{Zn}$.

The biochemical oxygen demand (BOD) is the amount of oxygen required by bacteria to decompose organic material in the water under aerobic conditions. The chemical oxygen demand (COD) is an estimate of the total available carbon and other food source for oxidation by chemical and biochemical reactions. The COD is determined using a spectrophotometer after oxidization with premixed COD reagents (USEPA, 1989). For BOD, the water samples collected at the sites are stored at $4{ }^{\circ} \mathrm{C}$ and analyzed for oxygen within 24 hours. The samples are diluted 2, 6, and 10 times and incubated for five days. The comparison of oxygen remaining in the samples with its original counterpart is used to calculate the BOD.

\section{Effect of alfalfa cutting frequency on soil water use}

Model simulations on water use by alfalfa as a function of cutting frequency indicated a higher water use by a fixed-schedule two-cut crop than a floating schedule three-cut crop (Peng et al., 1994). At an ongoing alfalfa varietal evaluation and cutting frequency experimental site at Morris, we installed $3.05-\mathrm{m}(10-\mathrm{ft})$ long neutron probe access tubes on October 24,1996 . The objective was to monitor water use by alfalfa as a function of frequency of harvest. The treatments included 8 plots of alfalfa variety 5444 with 4 plots each scheduled for two cuttings and three cuttings, respectively. After snow-melt in April 1977, soil water contents on the alfalfa plots were measured every week. The difference in profile water contents between two successive readings were used to calculate crop water use by alfalfa. 


\section{Results and Discussion}

\section{Runoff and pollutant delivery from paired watersheds at Morris}

\section{The snow-melt and runoff events of Spring 1997}

Table 1 below shows the monthly summary of precipitation and temperatures with deviations from 110-yr averages shown in the parenthesis. Except for February, the winter months of 1996-97 were colder than normal and the station received above normal precipitation and record amounts of snow fall. The unusually high precipitation of ice sleet during November 15-17, 1996 also produced a layer of ice specially on the relatively smooth alfalfa fields.

Table 1: Monthly summary of average daily temperature $\left({ }^{\circ} \mathrm{C}\right)$ and total precipitation $(\mathrm{mm})$ during November 96 to September 97 at Morris, Minnesota. The numbers in parenthesis denote above $(+)$ or below $(-)$ the 110 year $(1886-1996)$ averages.

\begin{tabular}{|c|c|c|c|c|}
\hline Month & $\begin{array}{l}\text { Average Maximum } \\
\text { Temperature }\end{array}$ & $\begin{array}{l}\text { Average Minimum } \\
\text { Temperature }\end{array}$ & Precipitation & Snow Fall \\
\hline & \multicolumn{2}{|c|}{$\left({ }^{\circ} \mathrm{C}\right)$} & \multicolumn{2}{|c|}{$\overline{(\mathrm{mm})}$} \\
\hline November-96 & $-2.8(-6.8)$ & $-10.8(-4.4)$ & $59.4(34.8)$ & $368(244)$ \\
\hline December-96 & $-9.8(-5.4)$ & $-17.6(-3.1)$ & $18.5(1.5)$ & $267(97)$ \\
\hline January-97 & $-11.0(-3.2)$ & $-20.8(-2.0)$ & $57.2(40.1)$ & $650(455)$ \\
\hline February & $-4.4(0.7)$ & $-15.4(1.0)$ & $7.9(-9.1)$ & $130(-48)$ \\
\hline March & $-0.4(-2.8)$ & $-10.5(-2.4)$ & $55.6(26.9)$ & $577(373)$ \\
\hline April & $9.6(-2.9)$ & $-1.1(-1.4)$ & $68.6(11.2)$ & $41(-43)$ \\
\hline May & $20.1(-2.8)$ & $7.0(-1.9)$ & $39.6(-35.6)$ & -- \\
\hline June & $25.0(2.6)$ & $14.8(2.1)$ & $63.7(-35.8)$ & - \\
\hline July & $28.1(-2.1)$ & $15.2(0.8)$ & $130.6(41.1)$ & -- \\
\hline August & $27.0(-1.9)$ & $13.8(0.3)$ & $99.6(22.6)$ & -- \\
\hline September & $21.6(2.2)$ & $8.4(1.9)$ & $33.0(-24.4)$ & -- \\
\hline
\end{tabular}

The four watersheds received various amounts of snowfall and snow drift during the winter of 1996-97. A snow course survey was conducted between December ' 96 and February ' 97 to measure the depth and density of snow every 10 meters in a north-south diagonal transect of about 200 meters at each field. Table 2 summarizes the average water equivalent of snowpack at the four plots.

The snow water equivalent data show a progressive increase in snow depth and density during the winter. Due to frequency of dominant north-west blizzards, significant amount of snow drifted from adjoining fields into the western watershed (Plot 8).

Figure 2-a shows the temperature and rainfall distribution during snow-melt periods between March 21 and April 8, and Fig. 2-b shows the runoff hydrographs for the four plots. The spring 1997 snow-melt started on March 21 on the eastern half plots of alfalfa (Plot-5) and corn (Plot-6), but the flow was low during the day and it froze during the night. The western half of the watershed (plots 7 and 8) started yielding water on March 26 when high temperatures during the day stayed above freezing. 
Table 2: Average water equivalents and density of snow-pack measured on 200-m long transect at each watershed.

\begin{tabular}{|c|c|c|c|c|c|}
\hline \multirow[b]{2}{*}{ Date } & \multicolumn{2}{|c|}{ Alfalfa } & \multicolumn{2}{|c|}{ Corn } & \multirow{2}{*}{$\begin{array}{c}\text { Average } \\
\text { Snow } \\
\text { Density }\end{array}$} \\
\hline & Plot 5 & Plot 8 & Plot 6 & Plot 7 & \\
\hline & \multicolumn{4}{|c|}{$(\mathrm{mm})$} & $\left(\mathrm{gm} / \mathrm{cm}^{3}\right)$ \\
\hline $12 / 12 / 96$ & 42 & 42 & 39 & 42 & 0.215 \\
\hline $1 / 3 / 97$ & 64 & 83 & 56 & 59 & 0.267 \\
\hline $1 / 21 / 97$ & 95 & 148 & 76 & 87 & 0.309 \\
\hline $2 / 18 / 97$ & 153 & 249 & 127 & 142 & 0.434 \\
\hline 3/20/97 (est.) & 182 & 308 & 146 & 166 & - \\
\hline
\end{tabular}

From March 26, the flow continued on all plots during the day and slowed down during the nights and early morning hours due to below freezing temperatures. Significant snow-melt occurred between March 31 and April 3 when both day and night temperatures increased above freezing (Fig. 2-a). The snow-melt ended on April 1 on Plot 5, April 3 on Plot 6, April 4 on Plot 7. The snow-melt and sub-surface flow continued to trickle on Plot 8 (which had the deepest depths of snow at lower end of field) until April 14.

The amount of runoff from each plot depended on amount of snow, the aspect, and surface characteristics determined by the cropping system (Fig. 2-b). Even though of equal area, the south-west facing corn field (Plot 7) yielded more water than the adjacent south-east facing field of corn (Plot 6). Similarly, the smaller south-west facing alfalfa field (Plot 5) yielded more water than the south-west facing larger alfalfa field (Plot 8) even though the latter had more average depth of snow (Table 2). On an average, the alfalfa fields had more runoff than corn fields. When the total runoff is subtracted from the total snow and rainfall inputs, on average, the alfalfa fields also infiltrated more water than the corn fields (Table 3).

Figure 3 shows the relationship between the cumulative runoff amounts and the load of sediments coming from each plot. At a given amount of runoff, both corn fields yielded more sediments than both the alfalfa fields. The graph clearly manifests the role of alfalfa in protecting the soil surface against the erosive forces of running water and raindrop impact.

Table 3 summarizes the amounts of snow, rainfall, snow-melt runoff, rainfall-runoff, infiltration, and sediment load due to snow-melt, and due to rainfall-runoff on the four plots. About 50-mm (2-inch) of rain on April 5 and 6 contributed to about 14\% increase in runoff from alfalfa field (Plot 5) and about 19 and $25 \%$ of total flow in the two corn fields. The rainfall contribution to sediment load was $25 \%$ in the alfalfa field (Plot 5) and about 41 to $48 \%$ on the corn field plots 6 and 7, respectively. On alfalfa Plot 8, due to continuation of snow-melt flow during April 5 and 6, the flow amounts between snow-melt and rainfallrunoff could not be discerned.

While the alfalfa Plot 5 produced higher runoff (Fig. 2-b), the sediment load per unit of runoff was significantly lower than both the corn plots (Fig. 3, Table 3). The sediment load due to rainfall-runoff shows that the raindrop impact doubled and quadrupled the sediment transport capacity of runoff on all plots. Compared to conventional tillage, the high residue, corn plots had about $63 \%$ surface cover (see last row on Table 3), and yet, the alfalfa cover protected soil from erosion better than the well managed corn plots. While there was no significant difference in the amount of total runoff, analysis of variance showed that corn had significantly higher $(p=0.025)$ average sediment load than alfalfa. 


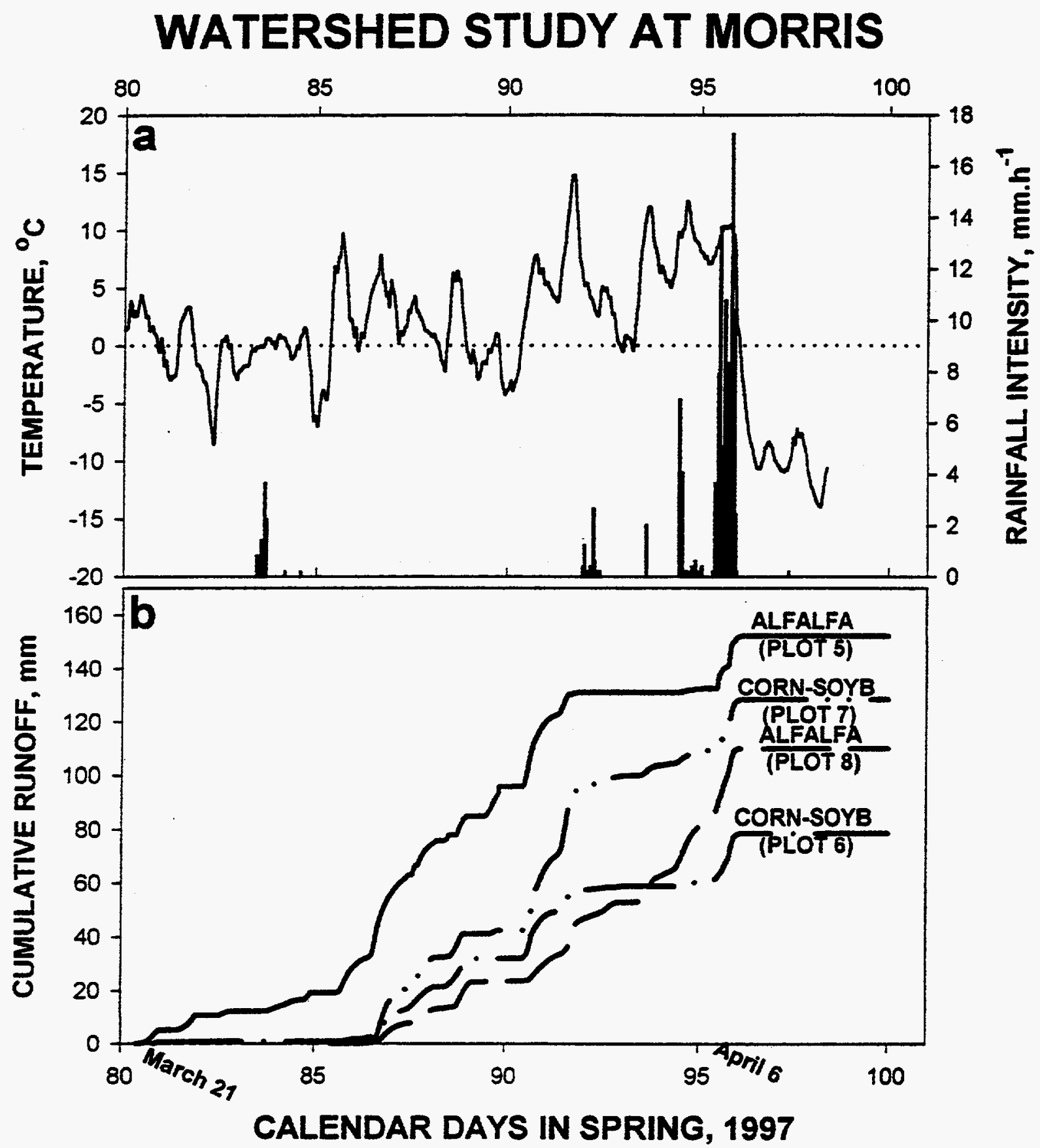

Fig. 2: (a) Distribution of average air temperature and rainfall, and

(b) runoff hydrographs of the four watershed plots. 


\section{WATERSHED STUDY AT MORRIS}

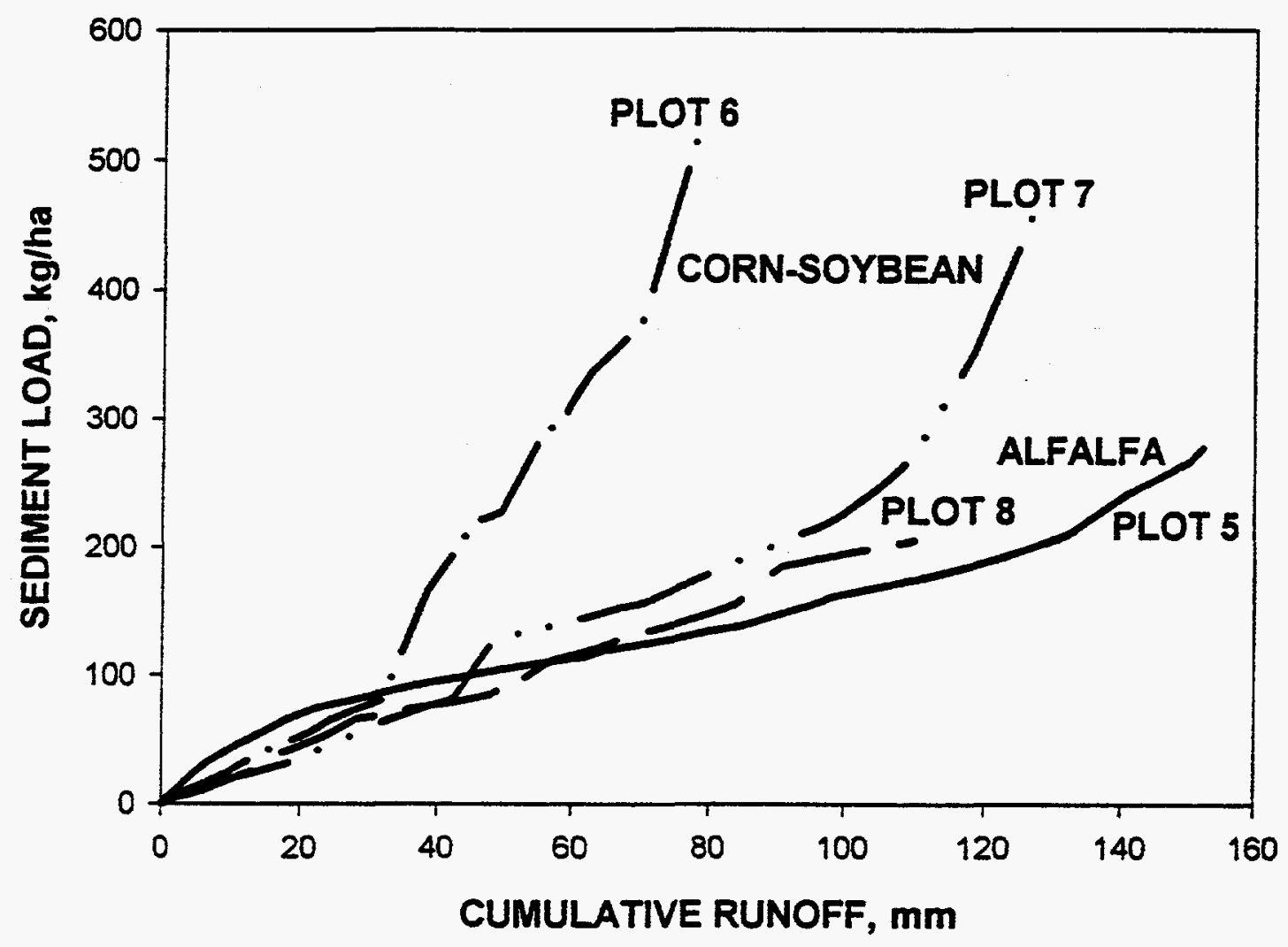

Fig. 3: Sediment load vs. cumulative runoff from the four watershed plots during spring-1997 at Morris. 
Figure 4 shows the distribution of different forms of phosphorus in runoff water. Figure 4-a, 4-b, and 4-c show that corn fields in general yielded more DMRP, bioavailable $P$, and total $P$ than alfalfa. This does not necessarily indicate an effect due to crop rotation. It is suspected that the higher levels of phosphorus in corn plots may be due to residual effect of manuring and fertilization history of the runoff plots.

Figures 5-a and 5-b show the distribution of ammonium and nitrate nitrogen in spring-melt runoff water. In general, the alfalfa fields yielded more ammonium and the corn fields yielded more nitrates. Again, at the state of this preliminary and one-time spring-melt data, it can not be discerned whether these differences are due to crop rotation or due to residual effects of management history of these plots. Compared to sediment load, phosphorus, and nitrogen, no definite trend was observed in loading of BOD (Fig. 6-a) and COD (Fig. 6-b) in the runoff water.

Table 4 summarizes the total load of pollutants coming from each of the four watersheds during the spring runoff event of 1997 . Both one way and two-way analysis of variance was performed on the cumulative amounts listed in Table 4. The one way analysis assumed the four fields as two observations each of corn and alfalfa. For two way analysis, we assumed plots with similar aspects as replications. Of the variables listed in Table 4, only total phosphorus (TP) showed a significant difference between alfalfa and corn. As discussed above, this could be an anomaly that needs to be evaluated with continued monitoring residual soil $\mathrm{P}$ and runoff $\mathrm{P}$ over a period of time.

\section{Precipitation and runoff events during the summer of 1997 at Morris}

About $425 \mathrm{~mm}$ of rain precipitated at Morris from May to October 15, 1997 (Table 1). Of which, six events with rainfall amounts greater than equal to $25.4 \mathrm{~mm}$ (1") yielded some runoff on at least one of the four watersheds. These events occurred on June 29, July 2, July 8, July 25, August 6, and August 19. However, significant amounts of runoff occurring from all the plots at a given event was very limited. The amount of runoff from each plot depended upon the intensity of rainfall, the duration of rainfall, the soil conditions, and the crop canopy. While the east-facing soybean plot (Plot 6) yielded the most frequent runoff events, the alfalfa plot with same aspect (Plot 8) yielded the least runoff.

Figure 7 shows example hydrographs of rainfall events on July - 02, July 25 , and August 19. During July 02 and July 25 intensive rainfall events, when soybean canopy had not completely covered the ground, most of the runoff occurred from the soybean plots. On August 19, a less intensive but long duration rainfall, produced similar amounts of runoff from two soybean (Plot 6) and alfalfa plots (Plot 5).

Table 5 summarizes concentrations of pollutants in the runoff samples collected during the summer precipitation events at Morris. The soybean plots yielded more samples with higher sediment load, COD, and nitrate while the alfalfa plots yielded more dissolved phosphorus. At the time of this reporting, the data from individual events from all the plots are being processed to calculate details of runoff and pollutant loading from each event. 


\section{WATERSHED STUDY AT MORRIS}

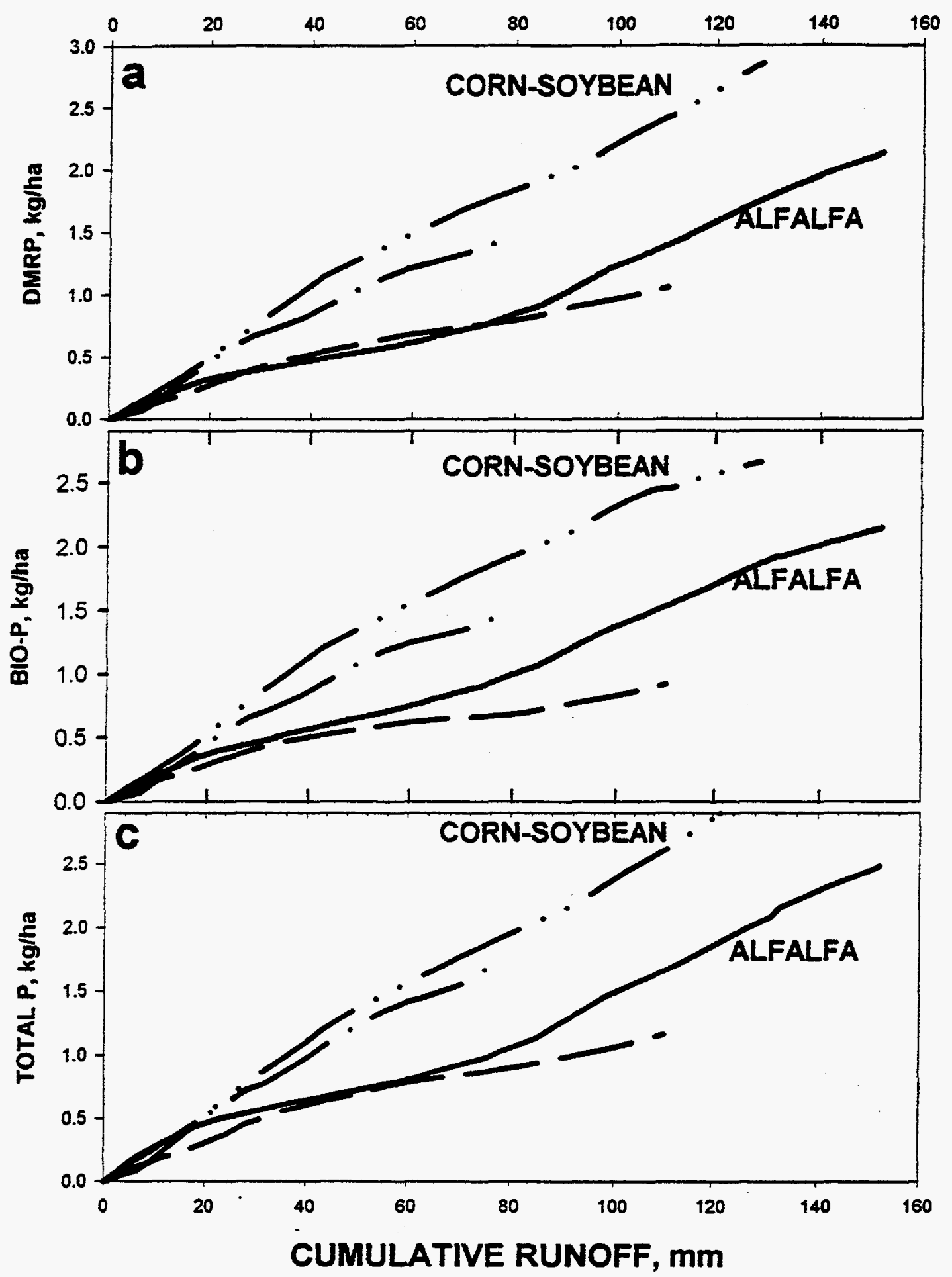

Fig. 4: Loadings of phosphorus vs. cumulative runoff:

(a) DMRP, (b) Bioavailable P, and (c) Total Phosphorus 


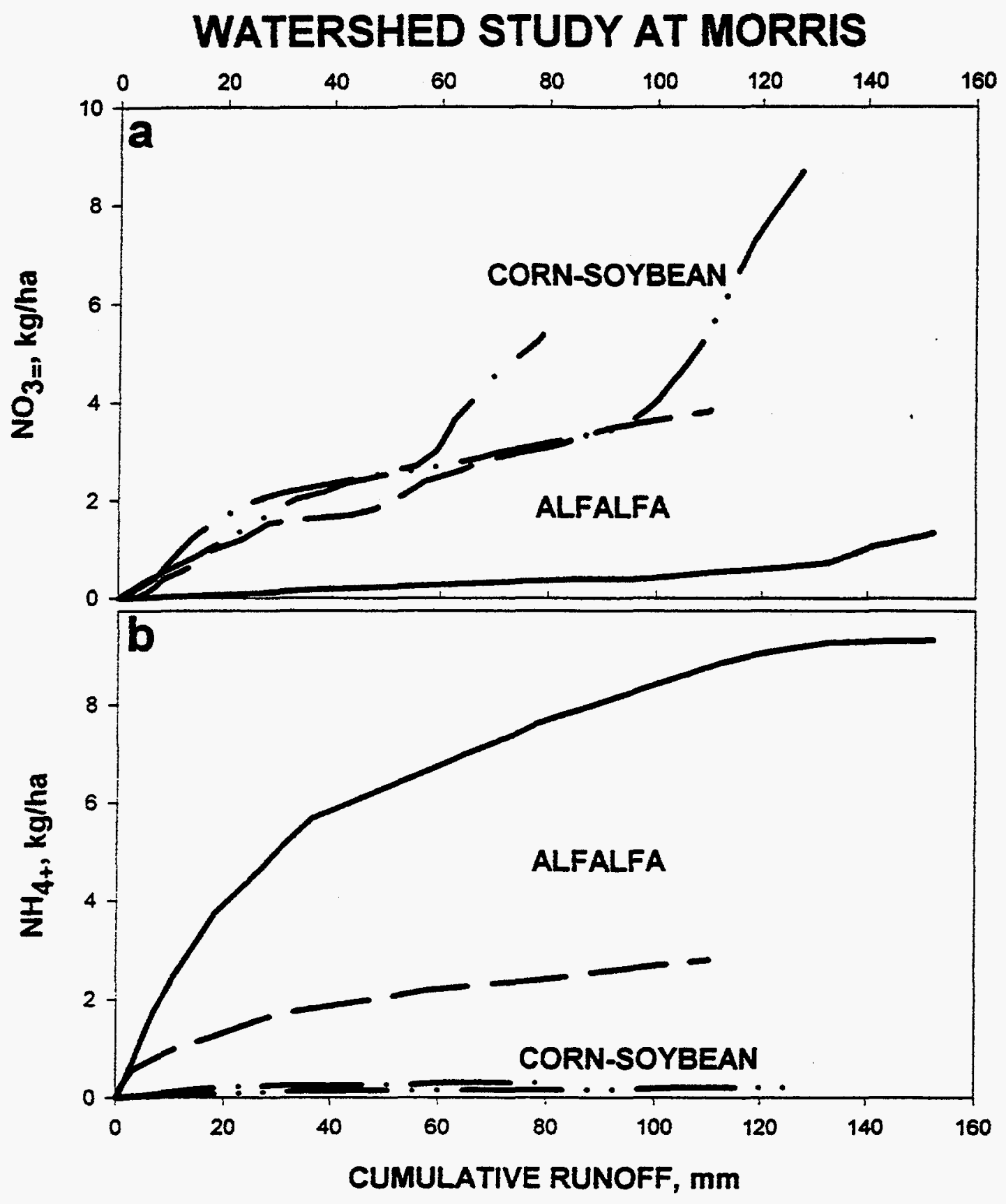

Fig. 5: Loadings of nitrogen vs. cumulative runoff:

(a) nitrate, and (b) ammonium. 


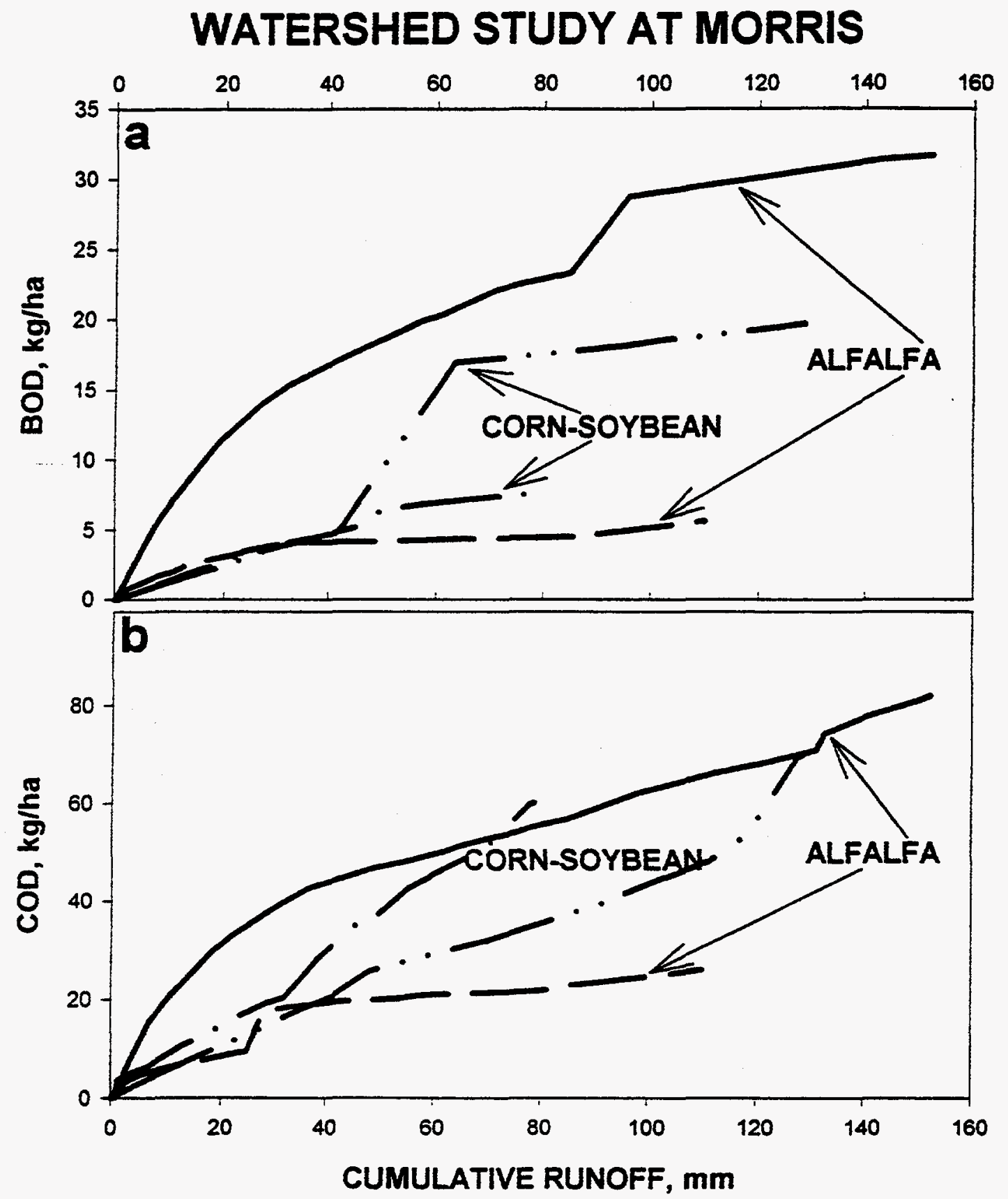

Fig. 6: Loadings of (a) biochemical oxygen demand (BOD) and, (b) chemical oxygen demand (COD). 
Table 3: Summary of cumulative rainfall, runoff, sediment load, and sediment transport per unit of runoff due to snow-melt and precipitation during spring of 1997 at Morris.

\begin{tabular}{|c|c|c|c|c|c|c|c|}
\hline \multirow[b]{2}{*}{ Source of runoff and sediments } & \multicolumn{3}{|c|}{ Alfalfa } & \multicolumn{3}{|c|}{ Corn-Soybean } & \multirow[b]{2}{*}{$p>F^{\square O}$} \\
\hline & Plot 5 & Plot $8^{r}$ & Mean & Plot 6 & Plot 7 & Mean & \\
\hline \multirow{2}{*}{\multicolumn{8}{|c|}{ Snow-melt runoff }} \\
\hline & & & & & & & \\
\hline Runoff, mm & 131 & & & 59 & 105 & & \\
\hline Sediment yield, $\mathrm{kg} \mathrm{ha}^{-1}$ & 208 & & & 304 & 245 & & \\
\hline Sediment load in runoff, $\mathrm{kg} \cdot \mathrm{ha}^{-1} \cdot \mathrm{mm}^{-1}$ & 1.6 & & & 5.2 & 2.3 & & \\
\hline \multicolumn{8}{|l|}{ Rainfall-Runoff } \\
\hline Rain on April 5-6, mm & 47 & 51 & & 54 & 51 & & \\
\hline Runoff, mm & 21 & & & 20 & 24 & & \\
\hline Sediment yield, $\mathrm{kg} \mathrm{ha}^{-1}$ & 70 & & & 214 & 229 & & \\
\hline Sediment load in runoff, $\mathrm{kg} \mathrm{ha}^{-1} \cdot \mathrm{mm}^{-1}$ & 3.3 & & & 10.8 & 9.6 & & \\
\hline \multicolumn{8}{|l|}{ Total } \\
\hline Rain + Snow, mm & 229 & 359 & 294 & 200 & 217 & 209 & 0.45 \\
\hline Runoff, mm & 152 & 111 & 131 & 79 & 129 & 104 & 0.09 \\
\hline Infiltration, $\mathrm{mm}$ & 77 & 248 & 163 & 121 & 84 & 105 & 0.55 \\
\hline Sediment yield ${ }^{\mathrm{DO}}$, kg.ha ${ }^{-1}$ & 277 & 208 & 243 & 519 & 474 & 496 & 0.14 \\
\hline Sediment load in runoff, $\mathrm{kg} \cdot \mathrm{ha}^{-1} \cdot \mathrm{mm}^{-1}$ & 1.8 & 1.9 & 1.85 & 6.6 & 3.7 & 5.1 & 0.14 \\
\hline Avg. surface cover after snow-melt, \% & 74.5 & 83.0 & 78.8 & 61.0 & 65.5 & 63.3 & \\
\hline
\end{tabular}

Due to continued snow-melt from Plot 8 on April 5 and 6, the flow volumes due to snow-melt and rainfallrunoff could not be discerned. ${ }^{\square}$ The probability ( $p$ ) of significant differences between treatment means was evaluated by F-test with a two-way analysis of variance method.

Table 4: Summary of total amounts of pollutants on runoff water from the four watersheds during spring of 1997 at Morris.

\begin{tabular}{|c|c|c|c|c|c|c|c|}
\hline \multirow[b]{2}{*}{ Constituents in Runoff Water } & \multicolumn{3}{|c|}{ Alfalfa } & \multicolumn{3}{|c|}{ Corn-Soybean } & \multirow{3}{*}{$\mathbf{p}>\mathbf{F}^{p}$} \\
\hline & Plot 5 & Plot 8 & Mean & Plot 6 & Plot 7 & Mean & \\
\hline & \multirow{2}{*}{\multicolumn{7}{|c|}{ - }} \\
\hline Oxygen Demand & & & & & & & \\
\hline Biochemical (BOD) & 31.7 & 5.6 & 18.7 & 7.6 & 19.7 & 13.6 & 0.60 \\
\hline Chemical (COD) & 82.1 & 26.3 & 54.2 & 60.3 & 69.8 & 65.1 & 0.72 \\
\hline \multicolumn{8}{|l|}{ Phosphorus } \\
\hline Dissolved (DMRP) & 2.14 & 1.07 & 1.61 & 1.45 & 2.86 & 2.16 & 0.19 \\
\hline Bio-available & 2.15 & 0.93 & 1.54 & 1.47 & 2.66 & 1.57 & 0.96 \\
\hline $\operatorname{Total}^{\square}$ & 2.48 & 1.17 & 1.83 & 1.75 & 3.09 & 2.39 & 0.02 \\
\hline \multicolumn{8}{|l|}{ Nitrogen } \\
\hline Ammonium & 9.30 & 2.82 & 6.06 & 0.31 & 0.22 & 0.26 & 0.33 \\
\hline Nitrate & 1.34 & 3.90 & 2.62 & 5.37 & 8.92 & 7.15 & 0.88 \\
\hline
\end{tabular}

${ }^{0}$ The probability ( $p$ ) of significant differences between treatment means was evaluated by $F$-test with a twoway analysis of variance method. 


\section{RAINFALL - RUNOFF HYDROGRAPHS MORRIS, MN, 1997}
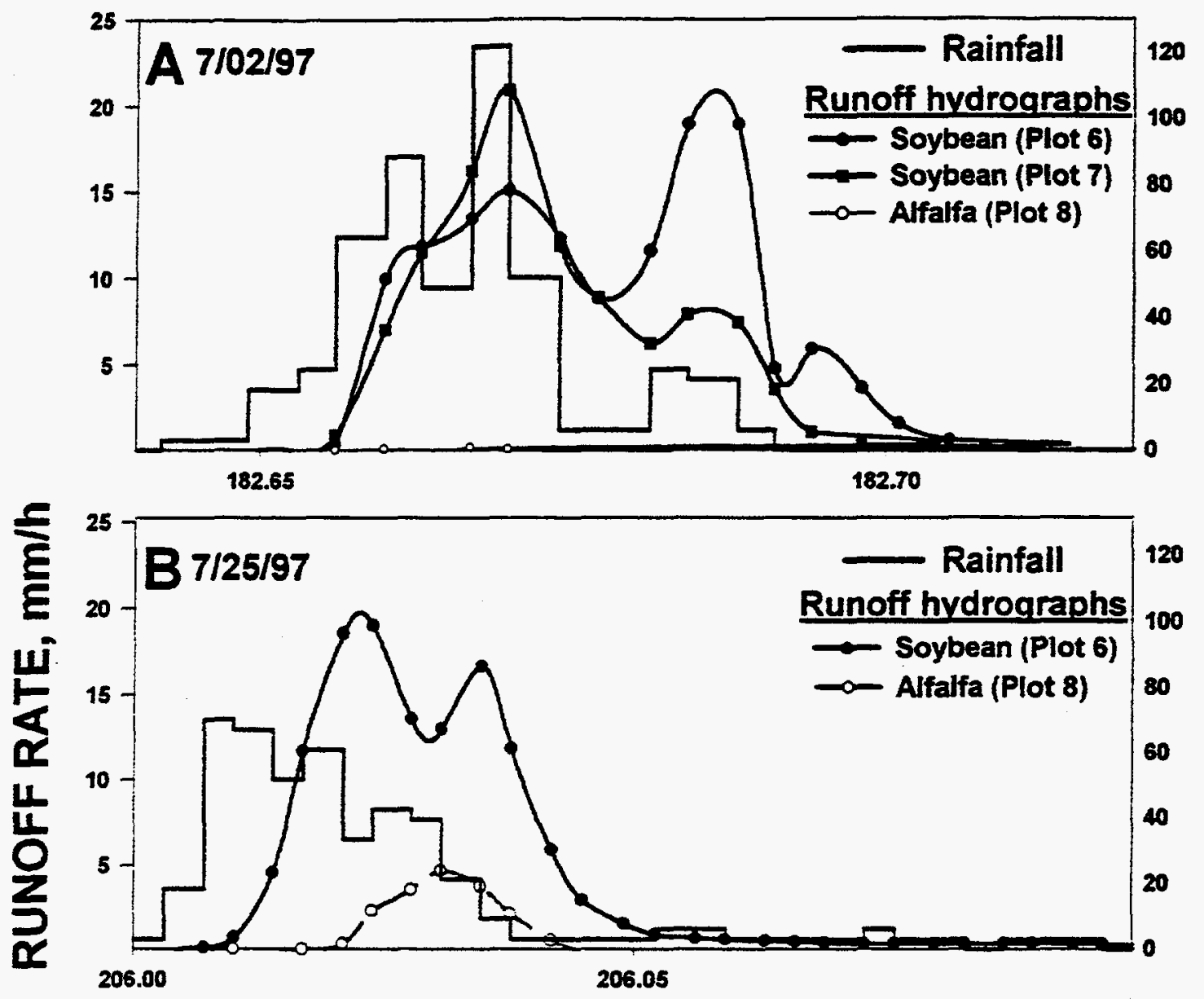

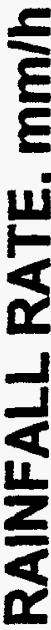

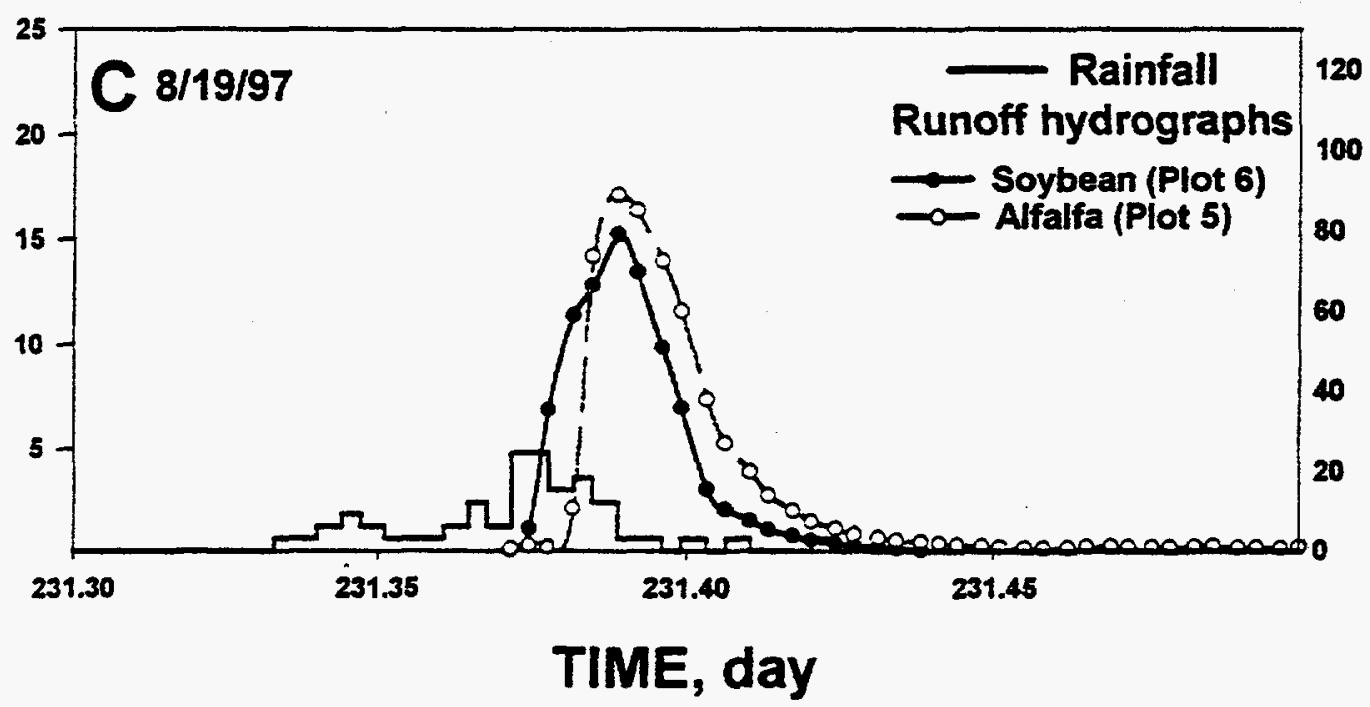

Fig. 7: Examples of rainfall-runoff hydrographs from significant precipitation events at Morris, MN during summer of 1997

Page (19) 
Table 5: Summary of sample counts and concentrations of pollutants on runoff water from the four watersheds during summer precipitation events of 1997 at Morris.

\begin{tabular}{|c|c|c|c|c|c|c|c|}
\hline \multirow[b]{2}{*}{ Constituents in Runoff Water } & \multicolumn{3}{|c|}{ Alfalfa } & \multicolumn{3}{|c|}{ Corn-Soybean } & \multirow[b]{2}{*}{$\mathbf{p}>\mathbf{F}^{\square}$} \\
\hline & Plot 5 & Plot 8 & Mean & Plot 6 & Plot 7 & Mean & \\
\hline Number of samples & 7 & 2 & & 13 & 5 & & \\
\hline & & & $--(m$ & -1) & $\ldots$ & 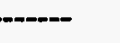 & \\
\hline Sediment Concentration & 409.9 & 379.0 & 394.4 & 756.5 & 1368.0 & 1062.3 & 0.26 \\
\hline Chemical $\mathrm{O}_{2}$ Demand (COD) & 88.6 & 127.9 & 108.3 & 190.3 & 216.8 & 203.6 & 0.21 \\
\hline \multicolumn{8}{|l|}{ Phosphorus } \\
\hline Dissolved (DMRP) & 1.76 & 1.34 & 1.55 & 0.65 & 0.72 & 0.69 & 0.13 \\
\hline Total $^{\square}$ & 2.09 & 1.81 & 1.95 & 1.67 & 2.22 & 1.95 & 0.98 \\
\hline \multicolumn{8}{|l|}{ Nitrogen } \\
\hline Ammonium & 0.57 & 1.44 & 1.01 & 0.37 & 0.80 & 0.59 & 0.64 \\
\hline Nitrate & 2.33 & 1.22 & 1.78 & 4.43 & 2.19 & 3.32 & 0.53 \\
\hline
\end{tabular}

${ }^{0}$ The probability ( $p$ ) of significant differences between treatment means was evaluated by $F$-test with a twoway analysis of variance method. 


\section{Effect of management on runoff and water quality}

Figure 8 shows the relationship between the amount of applied rainfall and the cumulative runoff observed on the eight plots. Input management, sequence of crops in rotation, and the residue cover influenced the amount of rain needed to initiate runoff and the steady state infiltration rates. The runoff started earliest on the four-year (CSOA) alfalfa plots with LPI management. The four-year soybean fields where alfalfa was planted two years ago with the organic management had the highest infiltration rates and needed the most rainfall to initiate runoff. The two year corn-soybean plots with LPI management performed in between the two.

The high infiltration rates of organic, soybean plots in the four-crop rotation following corn can be attributed to effects of tillage and presence of macro-pores due to decomposition of alfalfa and oat roots from previous crops. Both the prior crop of corn and soybean received primary tillage in the fall followed by secondary tillage in the spring. The high runoff and low infiltration rates off the four-crop rotation alfalfa plots with LPI management may be a result of compaction as no primary tillage was done on both the previous crops of oat and alfalfa.

Figure 9 shows the relationship between the amount of runoff and sediment load in the runoff water. Even though the amount of runoff from the soybean plots with organic management was small, the runoff water had high sediment loads. In general, regardless of input management, the alfalfa fields produced runoff with low sediment concentrations than the soybean fields. Similar to observations of watershed runoff data from Morris, the low sediment load on alfalfa covered fields is due to protection of soil against raindrop impact by higher surface cover.

Table 6 summarizes the average amount of applied rain needed to initiate runoff, total rain to get steady state runoff, total runoff, and the steady state infiltration rates measured from the eight plots. Table 7 lists the average loadings of sediments, dissolved and total phosphorus, and chemical oxygen demand (COD) in runoff water samples collected from each of the rainfall-runoff observations.

Two way analysis of variance to evaluate the effects of the four rotation-management treatments on the various infiltration and water quality parameters showed that :

- Soybean after two years following alfalfa under organic management had significantly higher infiltration capacity than other treatments.

- The runoff water coming from the same soybean plots had higher concentrations of sediments and total phosphorus. However, due to low total runoff, these plots yielded the lowest load of sediments and $P$.

- The rotation management treatments included in this rainfall simulation study did not show significant effects on the total amounts of sediments, phosphorus, and chemical oxygen demand.

- Further rainfall simulation experiments are needed to fully understand the interaction of crop sequence and management practices on a given soil. 
Table 6: Effect of crop rotation and surface cover on amount of rain applied to initiate runoff, total runoff, infiltration, and the final infiltration rates by simulated rainfall.

\begin{tabular}{|c|c|c|c|c|c|c|c|}
\hline Management & Crop ${ }^{\square}$ & $\begin{array}{c}\text { Surface } \\
\text { Cover } \\
(\%) \\
\end{array}$ & $\begin{array}{l}\text { Rain to } \\
\text { Initiate } \\
\text { Runoff } \\
\end{array}$ & $\begin{array}{c}\text { Total } \\
\text { Applied } \\
\text { Rain } \\
\end{array}$ & $\begin{array}{c}\text { Total } \\
\text { Runoff } \\
\text { nm) } \\
\end{array}$ & $\begin{array}{c}\text { Total } \\
\text { Infiltration }\end{array}$ & $\begin{array}{c}\text { Final } \\
\text { infiltration } \\
\text { rate } \\
\left(\mathrm{mm} \cdot \mathrm{h}^{-1}\right) \\
\end{array}$ \\
\hline Fertilizer (band & $\mathrm{CS}$ & 27.0 & 103.7 & 169.3 & 12.2 & 157.1 & 42.9 \\
\hline placed) & $\mathrm{CSOA}$ & 35.5 & 16.9 & 86.9 & 21.3 & 65.5 & 28.4 \\
\hline Manure & CSOA & 48.0 & 89.3 & 170.8 & 18.0 & 152.8 & 43.0 \\
\hline \multirow{2}{*}{$\begin{array}{l}\text { (mechanical } \\
\text { weed control) }\end{array}$} & $\mathrm{CSOA}$ & 25.5 & 165.3 & 205.3 & 3.5 & 201.8 & 69.3 \\
\hline & $p>F^{\square D}$ & 0.46 & 0.12 & 0.32 & 0.25 & 0.21 & 0.11 \\
\hline
\end{tabular}

${ }^{0}$ The crops ( $\mathrm{C}=$ corn, $\mathrm{S}=$ soybean, $\mathrm{O}=0 \mathrm{oat}$, and $\mathrm{A}=$ =alfalfa) written in bold-face letter denotes the residue from 1996 crop on which simulated rainfall was applied during April 21- 26, 1997 at Lamberton, $\mathrm{MN} .{ }^{\square}$ The probability (p) of significant differences among treatment means was evaluated by F-test with a two-way analysis of variance method.

Table 7: Effect of crop rotation on total load of sediments, dissolved phosphorus (DMRP), total phosphorus (TP), and chemical oxygen demand (COD) of runoff during rainfall simulation at Lamberton.

\begin{tabular}{|c|c|c|c|c|c|}
\hline Management & Crop Rotation & Sediment & DMRP & $\overline{\mathbf{T P}}$ & COD \\
\hline & & & $--(\mathrm{kg}$. & & - \\
\hline \multirow{2}{*}{$\begin{array}{l}\text { Fertilizer (band } \\
\text { placed) }\end{array}$} & CS & 197 & 0.013 & 0.104 & 12.3 \\
\hline & CSOA & 163 & 0.028 & 0.101 & 17.7 \\
\hline \multirow{3}{*}{$\begin{array}{l}\text { Manure } \\
\text { (Mechanical) } \\
\text { weed control) }\end{array}$} & CSOA & 161 & 0.025 & 0.072 & 13.0 \\
\hline & CSOA & 93 & 0.004 & 0.05 & 8.5 \\
\hline & $p>F$ & 0.75 & 0.53 & 0.70 & 0.62 \\
\hline
\end{tabular}

The crops $(\mathrm{C}=\mathrm{corn}, \mathrm{S}=$ soybean, $\mathrm{O}=0 \mathrm{oat}$, and $\mathrm{A}=$ alfalfa) written in bold-face letter denotes the residue from 1996 crop on which simulated rainfall was applied during April 21-26, 1997 at Lamberton, $\mathrm{MN} .{ }^{\square[}$ The probability (p) of significant differences among treatment means was evaluated by F-test with a two-way analysis of variance method. 


\section{SIMULATED RAINFALL AT LAMBERTON}

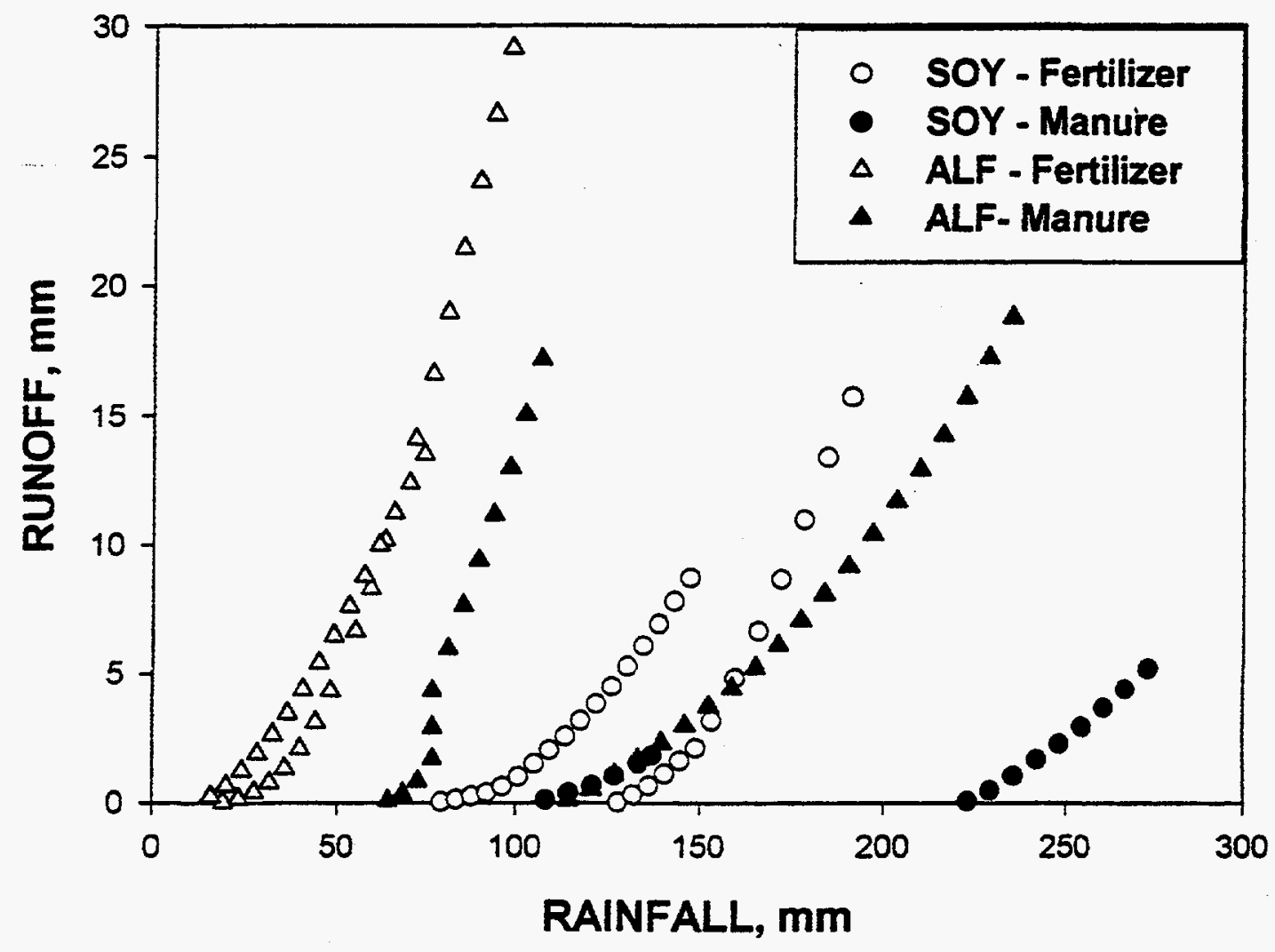

Fig. 8: Simulated rainfall and runoff from the eight variable input management study sites at Lamberton. 


\section{SIMULATED RAINFALL AT LAMBERTON, MN}

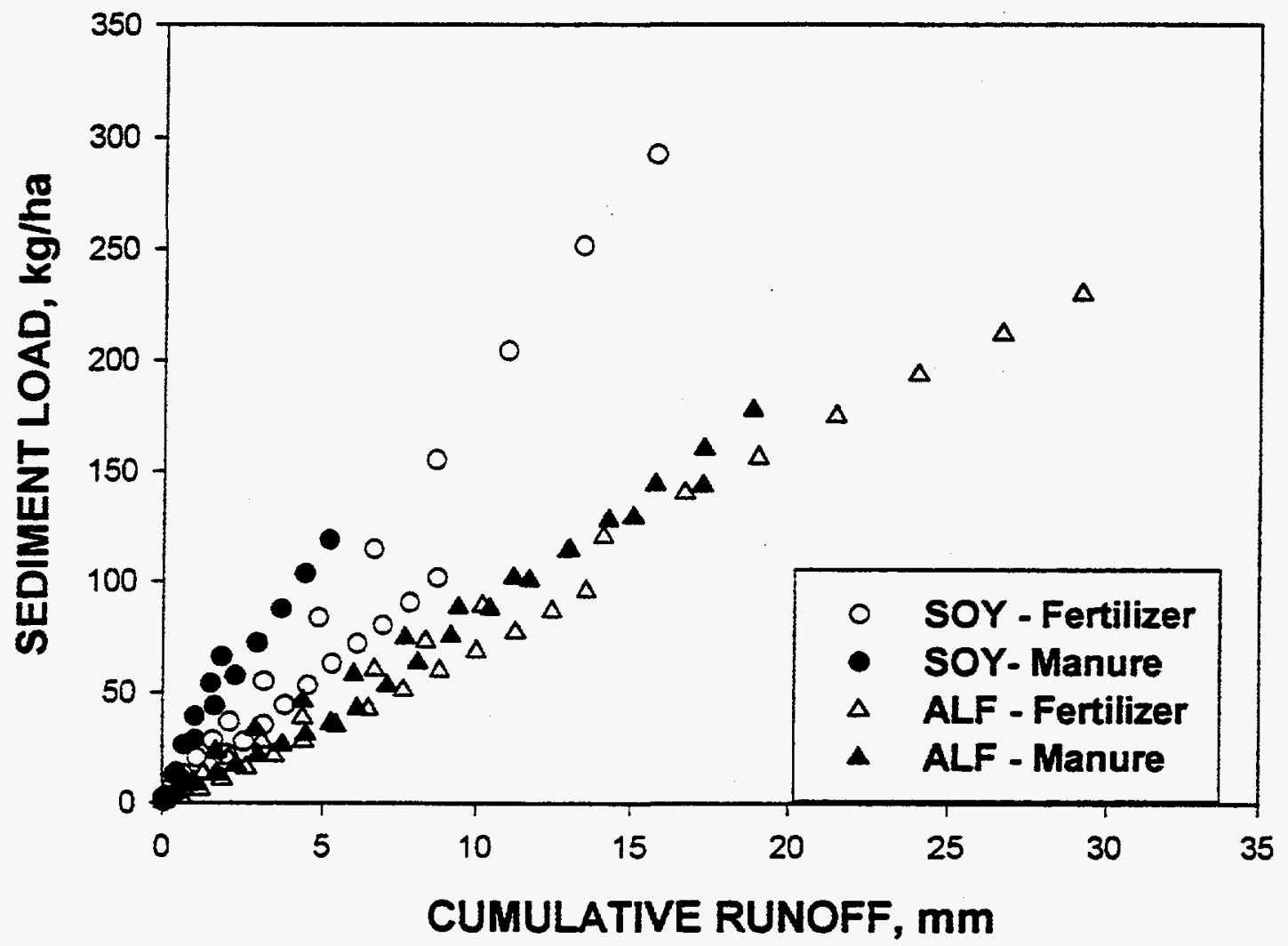

Fig. 9: Distribution of sediments as a function of cumulative runoff form the eight variable input management study plots at Lamberton. 


\section{Effect of alfalfa cutting frequency on soil water use}

Along with weekly measurements of soil water contents by the neutron probe, daily water use by alfalfa was also estimated using a modified Penman method (Doorenbos and Pruitt, 1977) with parameters adapted for west-central Minnesota by University of Minnesota, Extension Engineer, Jerry Wright (Wright, 1997).

Figure 10 shows the daily rainfall, and estimated evapotranspiration rates for the two-cut and three-cut experiments during 1997 at Morris, Minnesota. The three-cut crop was harvested on June-6, July-18, and August-27; the two-cut crop was harvested on June-25 and August-7. Until the first cut of the 3-cut treatment on June 6, the daily ET estimates are the same. After the first cut, the water use by the two treatments were estimated based upon the energy demand and stage of growth. The total estimated ET demands for the growing season (April-22 to October-9) for the 2-cut and 3-cut treatments were 611 and $579 \mathrm{~mm}$, respectively.

Figure $11 \mathrm{~A}$ shows the seasonal depletion of total water in the $3.05-\mathrm{m}(10-\mathrm{ft})$ soil profile. The soil profile was fully recharged after the snow-melt in April. As the greening and growth of alfalfa progressed, similar to the daily ET (Fig. 10), the soil water depletion continued at the same rate for both the two-cut and threecut treatments. After the first cut, the soil water use by the two treatments depended upon the energy demand, stage of growth, available soil water, and the precipitation amounts received during the rest of the growing season.

Figure $11 \mathrm{~B}$ shows the total consumptive use of water by alfalfa. The total consumptive use of water was cumulated for the growing season by accounting for soil water depletion, rainfall interception, and estimated ET for soil water recharge days. The total consumptive use of water from April 22 to October 9 for the two-cut and three-cut experiments were 650 and $607 \mathrm{~mm}$, of which, the net soil water discharge over the season were 298 and $323 \mathrm{~mm}$, respectively. In general, the two-cut treatments used about an inch $(25-\mathrm{mm})$ more soil water than the three cut treatments. The treatment effect on the cumulative soil water use was not significant by F-test with a two-way ANOVA $(p=0.46)$.

Figure $11 \mathrm{C}$ shows a comparison of the cumulative consumptive use calculated from measured soil water depletion and the cumulative estimated daily ET by the modified Penman method (Wright, 1997). For both the two-cut and three-cut treatments there was a strong linear relationship between the measured and estimated cumulative water use amounts. The coefficients of the linear relationships (shown as inset of Figure 11C) suggest that given the daily meteorological data and careful monitoring of growth stages of crop, alfalfa water use can be estimated with high degree of confidence. A note of caution in this relationship is that soil water storage during the 1997 growing season was above normal, and the estimated ET was used to cumulate consumptive use of water when soil water recharge occurred during periods of high rainfall in July and August. 


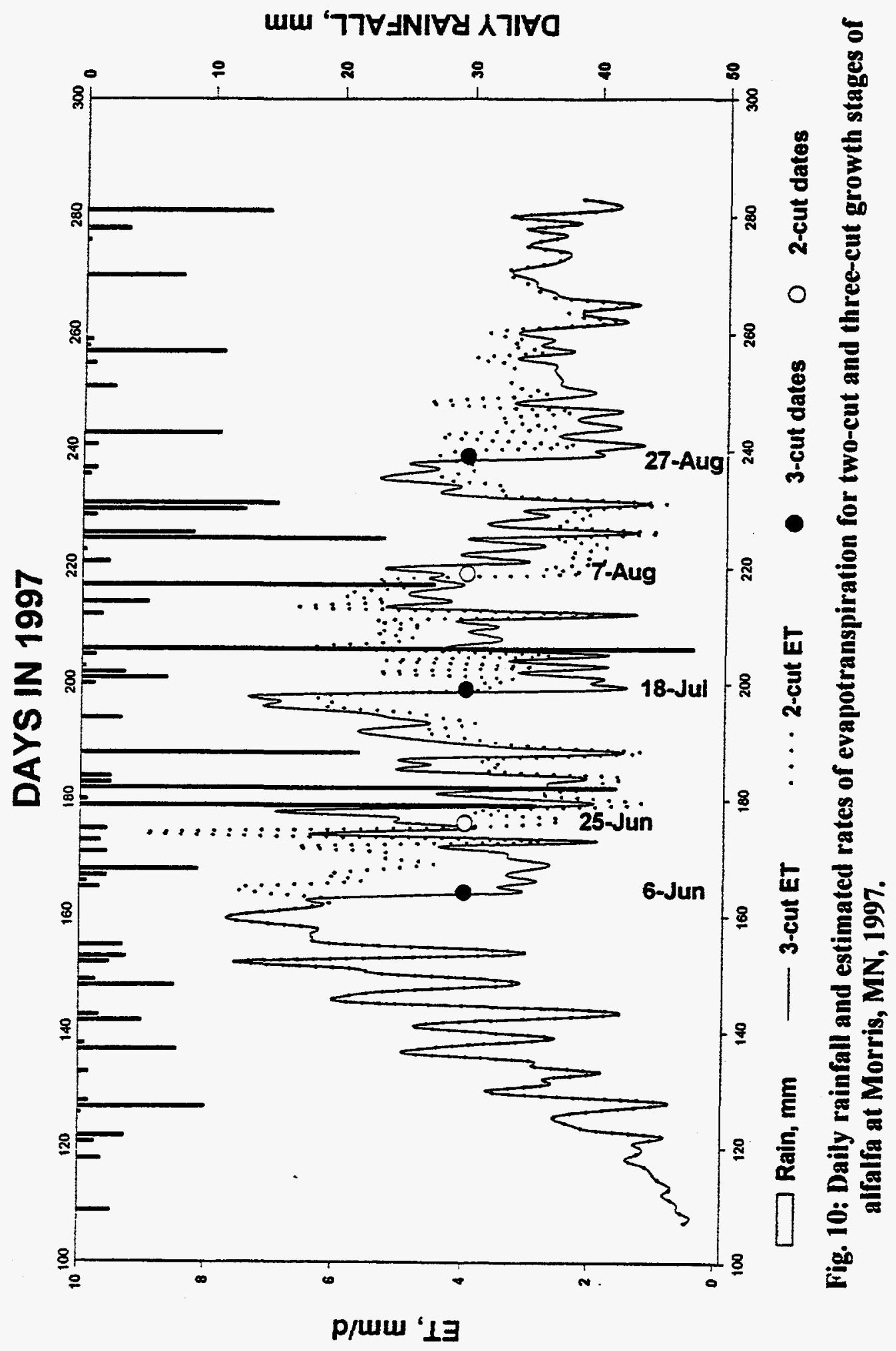

Page (26) 

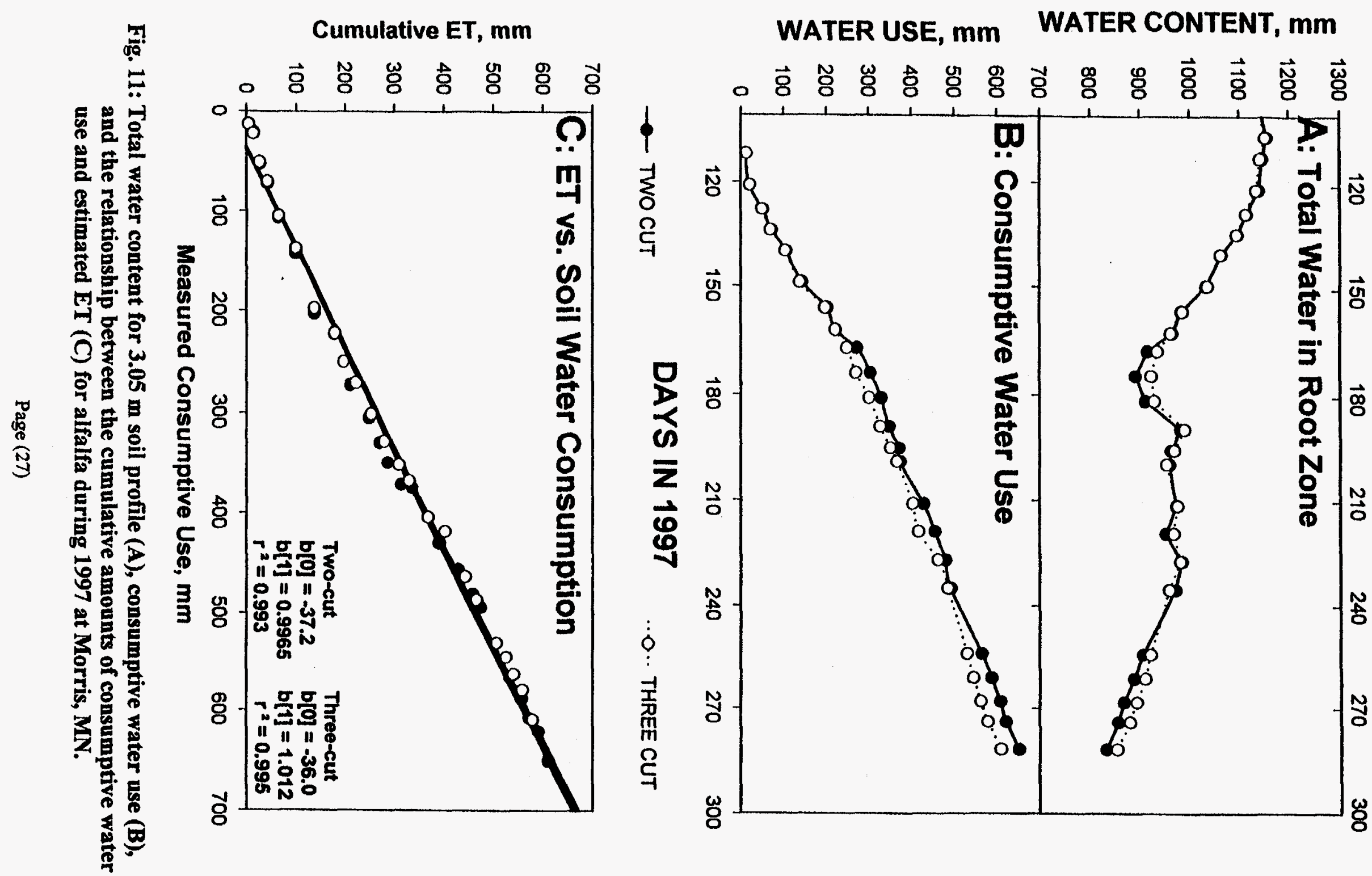


\section{Conclusions}

Field study was initiated in 1996 to compare the volume of runoff and pollutants coming from alfalfa and corn-soybean fields in western Minnesota. Two pairs of alfalfa and corn-soybean watersheds were instrumented at Morris. Water from each watershed passes through a 6-inch Parshall and a 4-inch PalmerBowlus flume in sequence. A data logger and a transducer - gas bubbler setup measures the height of water in the flumes. The data logger activates an electronic sampler to collect runoff samples for water quality. Water samples collected from runoff events are analyzed for total sediment, phosphorus, nitrogen, biochemical and chemical oxygen demand.

Runoff hydrographs of the record snow-melt event during the spring of 1997 at Morris show alfalfa fields yielding more runoff than corn-soybean fields while the latter produced more runoff during intense summer precipitation events. Chemographs relating the load of a suite of pollutants with runoff amounts for the spring-melt data show alfalfa fields yielding more ammonium while the corn fields yielding more nitrates, DMRP, bio-available $P$, and total $P$. There was no appreciable trend in the distribution of $B O D$ and COD. For both spring-melt and summer events, the nunoff from corn-soybean fields contained higher concentrations of sediments. Except for total $P$ at the spring-melt event, the water quality constituents between the well managed corn-soybean and alfalfa fields were not significantly different during 1997 $(p \leq 0.10)$. At this stage of preliminary observation, the treatment effects on total $P$ in the snow-melt runoff could not be attributed to crop rotation effects.

Simulated rainfall-runoff experiments conducted on existing crop rotation - input management study plots at Lamberton show that soybean fields under four-year (corn-soybean-oat-alfalfa) rotation with organic management had low runoff, high steady state infiltration rates, and lower amounts of sediments and phosphorus than corn-soybean fields with fertilizer inputs. This is attributed to improved soil quality as a result of aggregation and abundance of macropores due to manure application and potential residual effect of alfalfa biomass in the root zone.

The alfalfa harvesting frequency - water use study at Morris during 1997 showed that 2-cut alfalfa uses about 25-mm (1-inch) more soil water than 3-cut crop. The cutting treatment effects on soil water use were not significant. 


\section{Literature cited}

1. Carlson, R. M., R. I. Cabreara, J. L. Paul, J. Quick, and R. Y. Evans. 1990. Rapid direct determination of ammonium and nitrate in soil and plant tissue extracts. J. Plant Nutr. 21: 15191529.

2. Lewis, R. Royce, D. E. DeMartelaere, and E. L. Miller. 1971. Soil survey of Stevens County, Minnesota. USDA-SCS.

3. Metropolitan Waste Control Commission. 1994. Biochemical Oxygen Demand: 5-day $300 \mathrm{ml}$ bottle technique. Quality Control Laboratories, Metropolitan Waste Control Commission. Minneapolis, $\mathrm{MN}$.

4. Olson, S. R., and L. E. Sommers. 1982. Phosphorus. Methods of soil analysis. p. 403-430 in A. L. Page (ed). Methods of Soil Analysis. Part 2 - Chemical and Biological Properties. ASA/SSSA, Madison, WI.

5. Pang, X., J. F. Moncrief, and S. C. Gupta. 1997. Risk of yield loss resulting from the addition of alfalfa to corn and soybean rotations in southwestern Minnesota. In Sustainable Biomass Energy Production, Vol 1. Project Proposal prepared by University of Minnesota. pp. 48-68.

6. Perillo, C. A., P. M. Porter, D. R. Huggins, L. D. Klossner. 1996. Variable input crop management systems at the Southwest Experiment Station: 7-year management history and yields. Min. Agri. Exp. Stn. Publication, Soil Series \#142. pp. 41-50.

7. Rust, R. H., and R. A. Erickson. 1971. Soil Survey of the West Central Experiment Station. Minn. Agri. Exp. Stn. Publication, Soil Series 102.

8. Sharpley, A. N., S. J. Smith, O. R. Jones, W. A. Berg, and G. A. Coleman. 1992. The transport of bioavailable phosphorus in agricultural runoff. J. Environ. Qual., Vol. 21: 30-35.

9. US-EPA. 1971. Phosphorus, Total Method 365.4. USEPA Rep. 600/4-79-020.

10. US-EPA. 1971. Residue, Total Method 160.3. USEPA Rep. 600/4-79-020.

11. US-EPA. 1989. Standard Methods for the Examination of Water and Wastes. EPA-600/4-79-020.

12. Wright, J. 1997. Irrigation scheduling tools. A University of Minnesota Extension Service Bulletin. 


\section{Acknowledgment}

This research is funded in part by the Minnesota Valley Alfalfa Producers in support of the Minnesota Agri-Power Project and the Minnesota Department of Agriculture. The facilities and personnel support is provided by the University of Minnesota, Department of Soil, Water, and Climate, West Central Experiment Station at Morris, and the South West Experiment Station at Lamberton.

The principal investigators thank the technical support provided by Edward Dorsey and Juanjuan Xia of the Department of Soil Water and Climate, George Nelson of the West Central Exp. Stn., Dave Huggins and Lee Klossner of South West Exp. Stn., and Mark Zumwinkle of the Minnesota Department of Agriculture. 